\title{
Residual feed intake and its effect on carcass and meat characteristics of feedlot Zebu cattle ${ }^{1}$
}

\section{Julimar do Sacramento Ribeiro ${ }^{2}$, Tarcisio de Moraes Gonçalves ${ }^{2}$, Márcio Machado Ladeira², Fabrício Rodrigues Campos ${ }^{2}$, Rymer Ramiz Tullio ${ }^{3}$, Otávio Rodrigues Machado Neto², Dalton Mendes de Oliveira ${ }^{2}$, Marcelo Silva Bassi²}

\footnotetext{
1 Research financed by FAPEMIG

2 Universidade Federal de Lavras - UFLA.

${ }^{3}$ EMBRAPA Pecuária Sudeste.
}

\begin{abstract}
The objective of this study was to evaluate the residual feed intake (RFI) and its relation with performance, carcass and meat characteristics of Zebu animals. A total of 40 Zebu steers with initial age of 18 months and initial live weight of $350 \mathrm{~kg}$ were confined in feedlot for 112 days. The average daily gain (ADG) and dry matter intake (DMI) were obtained every 14 days. Residual feed intake was determined by the difference between observed and predicted DMI, based on the metabolic weight and the ADG. Animals were classified into the RFI groups: high ( $>0.5$ standard deviation of the mean - least efficient), medium ( \pm 0.5 standard deviation of the mean) and low $(<0.5$ standard deviation of the mean - most efficient). Daily cost with feeding and per kilogram of weight gain was determined. Characteristics of carcass (weight, yield, subcutaneous fat) meat ( $\mathrm{pH}$, shear force and color) were assessed. Animals with low RFI presented lower DMI. The variation in DMI between the low and the high RFI groups promoted difference in the daily cost with feeding and per kilogram of weight gain, with animals of low RFI presenting costs 5 and $9 \%$ lower, respectively. Carcass and meat characteristics differed over the RFI groups. The knowledge of the RFI of the animals enables a more efficient system, with reduction in the costs with feeding, without promoting alterations on the performance and carcass characteristics of the meat from Zebu animals.
\end{abstract}

Key Words: feed efficiency, meat quality, performance

\section{Introduction}

Feed intake is one of the factors of greatest importance in animal husbandry. Intake, in addition to being directly linked to animal performance, can correspond to $87 \%$ of the operational costs of production (Lopes et al., 2011). Therefore, improving feed efficiency appears to be a viable alternative for the reduction of the production cost in beef cattle raising (Lanna \& Almeida, 2004).

Many indices which evaluate feed efficiency have been proposed. Thus, due to its importance, the search for tools or methodologies which have accuracy in the measurement of this characteristic is constant in the scientific world. Recently, the parameter of feed efficiency named residual feed intake (RFI), defined by Kock et al. (1963), has been the target of studies, especially in the USA and Australia, aiming to achieve improvement in the productive efficiency of the cattle herd (Arthur et al., 2008).

The literature has reports of advantages obtained with RFI as a selection criterion in breeding programs of beef cattle. Among them are the improvement of feed efficiency
(Basarab et al., 2003; Arthur et al., 2008), improvement of productivity at the rearing sector and, consequently, reduction in the area necessary for the herd (Lanna \& Almeida, 2004), in addition to reduction in the excretion of methane and other pollutants (Cooperative Research Centre for Cattle and Beef Quality - CRC, 2004).

The main hindrance for the obtainment of RFI is the need to know the individual dry matter intake of the animals in a relatively long period of time, and this makes the estimation of this characteristic onerous (Wang et al., 2006). However, the cost of the intake estimations can be reduced when one utilizes indicators, as done with grazing animals (Arthur et al., 2008). Besides, it can be observed, in the literature, that animals with low RFI, i.e., more efficient animals, tend to present lower fat distribution over the carcass and possible alteration in their meat quality (McDonagh et al., 2001; Arthur et al., 2008).

The objective of this study was to evaluate the residual feed intake and its relation with performance, carcass characteristics and meat quality of feedlot Zebu animals. 


\section{Material and Methods}

The experiment utilized 40 Zebu steers (20 Nellore and 20 Tabapuã) of average initial age 18 months and average initial weight of $350 \mathrm{~kg}$ confined in two collective stalls with $30 \mathrm{~m}^{2}$ per animal; each stall had 10 animals of each breed. The feedlot facility was made of compacted soil and approximate declination of $5 \%$, with an area close to concrete feeder and dividers made of smooth wire. Collective drinkers were located in between the two stalls; feeders were placed transversally at the upper part of the pens, with 70 linear centimeters for each animal.

In the beginning of the adaptation period, with duration of 42 days, animals were weighed after fasting of solids and liquids for 16 hours and treatment against ecto and endoparasites. During the adaptation phase, animals were fed ad libitum with the same diet of the experimental period (Table 1), which was balanced to meet the NRC specifications (2000) for $1.2 \mathrm{~kg} /$ day weight gain.

The feed, in the form of complete diet, was supplied ad libitum to animals at 08:00 and 15:00h; leftovers were collected in the following morning and the amount of diet was adjusted every day to allow $5 \%$ leftovers.

At every 14 days, samples of the ingredients of the concentrate, the concentrate mix and the silage were collected for bromatological analyses, which were carried out according to Silva \& Queiroz (2002).

Weighing of the animals was performed at the end of each 14-day period, after fasting of solids and liquids for 16 hours. The average daily gain (ADG) obtained was calculated as follows:

$$
A D G=\frac{F L W-I L W}{\text { no. of days in the period }}
$$

Table 1 - Bromatological composition of the experimental diet supplied to feedlot Zebu animals

\begin{tabular}{|c|c|}
\hline Ingredient & $(\mathrm{g} / \mathrm{kg})$ \\
\hline Corn silage $^{1}$ & 398 \\
\hline Ground $\operatorname{corn}^{1}$ & 504 \\
\hline Soybean meal ${ }^{1}$ & 78 \\
\hline Mineral nucleus*1 & 20 \\
\hline \multicolumn{2}{|l|}{ Chemical composition } \\
\hline Dry matter $(\mathrm{DM})^{2}$ & 664 \\
\hline Crude protein $(\mathrm{CP})^{1}$ & 115 \\
\hline Neutral detergent fiber corrected for ash and protein (NDFap) ${ }^{1}$ & 305 \\
\hline Non-fibrous carbohydrate $(\mathrm{NFC})^{1}$ & 491 \\
\hline Ether extract $(\mathrm{EE})^{1}$ & 33 \\
\hline Total digestible nutrient $(\mathrm{TDN})^{1,3}$ & 740 \\
\hline \multicolumn{2}{|l|}{$1 \mathrm{~g} / \mathrm{kg}$ of dry matter. } \\
\hline \multicolumn{2}{|l|}{$2 \mathrm{~g} / \mathrm{kg}$ of natural matter. } \\
\hline \multicolumn{2}{|c|}{$\begin{array}{l}\text { Calculated according to the NRC }(2000):{ }^{*} \text { Guarantee levels per kilogram of } \\
\text { product is as follows: calcium - } 235 \text { g; phosphorus - } 45 \text { g; sulfur - } 23 \text { g; sodium - } \\
80.18 \text { g; zinc - } 2.38 \mathrm{mg} \text {; copper - } 625 \mathrm{mg} \text {; iron - } 1.18 \mathrm{mg} \text {; manganese } 312 \mathrm{mg} \text { : } \\
\text { cobalt - } 32 \mathrm{mg} \text {; iodine - } 41.6 \mathrm{mg} \text {; selenium - } 11.25 \mathrm{mg} \text {; A vit. - } 70.000 \text { UI; D3 } \\
\text { vit. - } 5.000 \text { UI; E vit. - } 15 \text { UI; and niacin - } 3.33 \mathrm{mg} \text {. }\end{array}$} \\
\hline
\end{tabular}

where FLW is the final live weight and ILW is the initial live weight of each period.

The average metabolic weight (AMW) was obtained from the average live weight (ALW), calculated based on the formula below:

$A M W=A L W^{0.75}$; average live weight was calculated as:

$A L W=I L W+\frac{(A D G * \text { no. of days in the period })}{2}$

The relative growth rate (RGR) was calculated according to the equation: $\mathrm{RGR}=100 *(\log$ final LW $-\log$ initial LW)/days in experiment; and the Kleiber ratio was obtained by dividing the ADG by $\mathrm{LW}^{0.75}$, as described by Sobrinho et al. (2011).

The dry matter intake (DMI) in each experimental period was determined by means of internal and external indicators (Valadares Filho et al. 2006). For the estimation of the excretion of fecal dry matter, the LIPE ${ }^{\circledR}$ indicator was utilized at the dosage of one capsule of $0.5 \mathrm{~g} /$ animal/day (Saliba, 2005), during the 10th, 11th and 12th days of each experimental period.

Feces collection was done according to the following procedures: at $10: 00 \mathrm{~h}$ and at $18: 00 \mathrm{~h}$ of the 11 th day, at 08:00 $\mathrm{h}$ and $16: 00 \mathrm{~h}$ of the 12 th day and at 06:00h and 14:00h of the 13 day of each period (Ladeira et al., 1999). These samples were pre oven-dried $\left(65^{\circ} \mathrm{C}, 72\right.$ hours) and ground in 1-mm mesh sieve; after, a composite sample per animal for each period was elaborated, based on the pre-dried weight.

Samples were sent to the Veterinary School of Universidade Federal de Minas Gerais, for LIPE ${ }^{\circledR}$ analyses by the Sarkanen \& Ludwig (1971) method. Chrome analyses were determined by near-infrared reflectance spectroscopy (NIRS), making use of a wavelength of 1,300 to 2,235 nm (Marten et al., 1985).

The indigestible dry matter (iDM) was obtained after in situ incubation for 240 hours, according to technique described Casali et al. (2008).

The estimated dry matter intake (DMI) was calculated by the formula:

$D M I=\frac{F E^{*} \text { fecal }[i D M]}{\operatorname{diet}[i D M]}$, in which FE is the excretion of fecal DM, in kg; fecal[iDM] is the concentration of iDM in the feces (\%) and diet[iDM] is the concentration of $\mathrm{IDM}$ in the diet (\%).

Feed conversion (FC) was obtained by the ration between DMI (kg/day) and ADG (kg/day); the inverse ratio was utilized to express feed efficiency (FE).

Residual feed intake (RFI) was calculated for each 14-day interval and also for the 70 experimental days (RFI). The RFI was determined by the difference between the observed intake and predicted intake. 
Predicted values of DMI (PDMI) were obtained by means of the REG procedure of the statistical software SAS (Statistical Analysis System, version 8.0); the observed intake regression was adjusted in function of AMW and ADG, as follows:

\section{$P D M I=\beta_{0}+\beta_{1}(A M W)+\beta_{2}(A D G)+\varepsilon$}

In order to study the residual feed intake, animals were classified as high RFI ( 0.5 standard deviation of the mean - least efficient), medium RFI ( \pm 0.5 standard deviation of the mean) and low RFI ( $<0.5$ standard deviation of the mean most efficient). The RFI classes were considered independent variables and the variance analysis was carried out by comparing animals according to their RFI values.

Regarding the variation of price of the ingredients over the feedlot period, the mean value of a kilogram of dry matter of feed was R\$0.35. The daily cost with feeding (DCF) per animal was determined by the amount of feed ingested (DMI $\mathrm{kg}$ /day) multiplied by the cost of the diet consumed. The cost with gain (CG) (R\$/kg gain) was determined by the ratio between DCF and ADG.

The data on rib-eye area, backfat thickness and rump fat thickness were determined in live animals, on the last experimental day. Ultrasound machine Aloka 500V (Corometrics Medical System, Wallingford, CT), with linear transducer of $3.5 \mathrm{MHz}$ was utilized. The images utilized for the measurement of rib eye area and backfat thickness were drawn between the 12th and 13th ribs, at the height of the longissimus thoracis. Rump fat thickness was measured on the junction of muscles biceps femoris and gluteus medium, between the ischium and the ileum, parallel to the vertebra, as described by Greiner et al. (2003).

The slaughter was conducted according to recommendations by RIISPOA (Brasil, 1997), in industrial slaughterhouse freezer under Federal Inspection (SIF). On the slaughtering line, liver, kidneys, heart and lungs of each animal were collected and weighed.

The hot carcass yield (HCY) was determined by the ratio between the carcass at the end of the slaughtering line and the slaughter weight.

Before and after carcass chilling, the reading of the $\mathrm{pH}$ was conducted ( 0 and 24 hours, respectively). Samples of the longissimus thoracis were extracted between the 9th and 11th ribs of the left half carcass for further laboratory analyses

The parameters of meat quality, color (CIELAB), shear force, weight loss by cooking and water retention capacity were evaluated at the laboratory of Embrapa Pecuária Sudeste, São Carlos, SP, according to methodologies described by Fernandes et al. (2008).

The data were grouped per breed and RFI and analyzed with the procedures of the statistical software SAS
(Statistical Analysis System, version 8.0); means were compared by the Tukey test $(\alpha=0.05)$.

\section{Results and Discussion}

There was no effect of breed on the variability of the characteristics studied $(\mathrm{P}<0.05)$, thus, the data presented correspond to the data obtained with all animals (Table 2).

One can observe that the dry matter intake (DMI) and the average daily gain (ADG) of the animals are within the values expected, given that they are close to the values found in the NRC (2000) for animals in this weight and age range. The values obtained for carcass characteristics are close to those found in the literature for animals with good performance at these characteristics (Menezes et al., 2005).

The DMI was positively correlated with average metabolic weight and ADG, which explains the inclusion of these variables in the regression equations for prediction of DMI (Table 3).

The carcass characteristics backfat thickness and rump fat thickness presented correlation with DMI, which indicates that the variations in these traits were independent of the variations observed for DMI. Such fact can be explained by the little variability for backfat and rump fat thickness presented by animals at this age; this variation was not enough to explain the alteration in the DMI. Thus, the inclusion of these characteristics in the intake prediction model is not justified, as suggested by Arthur et al. (2003) and Nkrumah et al. (2004).

Table 2 - Adjusted means, minimum and maximum values, coefficient of variation (CV) and standard error of the mean (SEM) of the different characteristics evaluated in feedlot Zebu animals

\begin{tabular}{lccccc}
\hline Item & Mean & Lowest & Highest & CV & SEM \\
\hline Initial LW, kg & 406 & 349 & 450 & 6.40 & 7.15 \\
Final LW, kg & 477 & 411 & 529 & 6.60 & 4.98 \\
MW, kg & 96.35 & 86.22 & 103.37 & 4.71 & 0.72 \\
ADG, kg & 1.14 & 0.62 & 1.61 & 21.78 & 0.04 \\
DMI, kg & 9.76 & 8.81 & 10.55 & 4.20 & 0.07 \\
DMIa, \% LW & 2.21 & 1.82 & 2.36 & 4.26 & 0.01 \\
DMIb, g/kgMW & 101.1 & 84.9 & 105.5 & 3.39 & 0.15 \\
FE & 0.12 & 0.06 & 0.23 & 25.37 & 0.01 \\
FC & 8.58 & 6.10 & 19.73 & 29.80 & 0.90 \\
DCF, R\$ & 3.45 & 3.07 & 3.74 & 4.54 & 0.02 \\
CG, R\$/kg & 3.08 & 2.01 & 5.58 & 24.80 & 0.13 \\
REA, cm ${ }^{2}$ & 61.15 & 50.10 & 75.70 & 10.37 & 1.00 \\
BFT, mm & 4.25 & 2.30 & 7.00 & 26.36 & 0.18 \\
RFT, mm & 5.88 & 2.70 & 8.70 & 25.99 & 0.24 \\
Liver, kg & 4.35 & 3.35 & 5.25 & 10.02 & 0.07 \\
Kidneys, kg & 0.88 & 0.70 & 1.15 & 11.63 & 0.02 \\
Heart, kg & 1.55 & 1.25 & 2.05 & 11.62 & 0.03 \\
Lungs, kg & 3.38 & 2.65 & 4.05 & 9.72 & 0.05 \\
\hline
\end{tabular}

LW - live weight; MW - metabolic weight; ADG - average daily gain; DMI - dry matter intake; DCF - daily cost with feeding; CG - cost with gain; FE - feed efficiency; FC - feed conversion; REA - rib-eye area; BFT - backfat thickness; RFT - rump fat thickness. 
Table 3 - Correlation between dry matter intake(DMI), metabolic weight (MW), average daily gain (ADG), backfat thickness (BFT) and rump fat thickness (RFT) of feedlot Zebu animals

\begin{tabular}{ccccc}
\hline Item & MW & ADG & BFT & RFT \\
\hline DMI & $0.87 * *$ & $0.42 * *$ & 0.02 & -0.19 \\
\hline
\end{tabular}

**significant $(\mathrm{P}<0.01)$.

MW - metabolic weight; ADG - average daily gain; DMI - dry matter intake; BFT backfat thickness; RFT - rump fat thickness.

If the magnitude of the correlation of average metabolic weight with DMI is higher, it may indicate that the variation in DMI, at this growth phase of the animals, is more dependent on average metabolic weight than on the ADG.

The dry matter intake, average metabolic weight (AMW) and average daily gain obtained in every period were utilized for adjustments of equations for the prediction of dry matter intake (PDMI) and the calculation of the average residual feed intake (ARFI) for the 70 experimental days. The multiple regression equations adjusted to estimate the predicted dry matter intake according to the period were: PDMI $=0.9692+0.08642($ AMW $)+0.3908($ ADG $)$.

$\mathrm{r}^{2}=0.59$ for period 1 ;

PDMI $=0.8880+0.0959($ AMW $)-0.1090$ (ADG).

$\mathrm{r}^{2}=0.63$ for period 2 ;

PDMI $=0.3091+0.0954($ AMW $)+0.2790($ ADG $)$.

$\mathrm{r}^{2}=0.64$ for period 3 ;

PDMI $=2.63850+0.0701($ AMW $)+0.4669($ ADG $)$.

$r^{2}=0.46$ for period 4 ;

PDMI $=3.0797+0.08062($ AMW $)+0.4237($ ADG $)$.

$\mathrm{r}^{2}=0.54$ for period 5 ; and

PDMI $=2.2767+0.0758($ AMW $)+0.2989(A D G)$.

$\mathrm{r}^{2}=0.79$ for the total period.

The $\mathrm{r}^{2}$ values verified in all the periods indicate good adjustment of equations for prediction of intake. However, the highest value was verified when the overall mean of the experiment was assessed, which corroborates the data from the literature, which state that the optimal time for measurement of the intake is of, at least, 70 days (Wang et al., 2006). Thereby, the results discussed in this paper refer to the RFI values obtained in the 70 experimental days, which is the total observation period.

The correlations between RFI and characteristics dry matter intake (DMI), feed efficiency (FE), feed conversion (FC) and daily cost with feeding (Table 4) indicate the that there was positive correlation between RFI and characteristics DMI, FC and daily cost with feeding.

The positive correlation between RFI and DMIb (g/kgAMW) (Table 4) may indicate that the animals with higher RFI values present greater requirement of metabolic energy for maintenance, and this expenditure can result in lower ADG for an equal DMI.
Similar results can be observed in the study of Cabral et al. (2008), in which the greater DMI (g/kgAMW) is directly linked to the maintenance requirement of the animals.

The positive correlation observed between RFI and FC (Table 4) indicates that, when seeking animals with better RFI, one gets improvement in FC. The low correlation value (0.33) between RFI and FC found in this study is close to those reported by Herd et al. (2003), which may indicate that different factors affect these characteristics.

The values of the daily cost with animal feeding and the RFI increased simultaneously (0.88 correlation).

The energy expenditure with maintenance behaves as a fixed cost: since more efficient animals (low RFI), comparatively, dilute their maintenance needs, the confinement of animals with lower RFI promotes decrease in the cost with feeding (Table 5).

No difference in the initial and final live weight of the animals was observed for the different RFI groups (Table 5), which is consistent with the similar ADG between the groups. This indicates that using the RFI for the evaluation

Table 4 - Correlation of residual feed intake (RFI), dry matter intake, feed efficiency and daily value of the feeding of feedlot Zebu animals

\begin{tabular}{cccccc}
\hline Item & DMIa & DMIb & FE & FC & DCF \\
\hline RFI & 0.06 & $0.49 * *$ & 0.16 & $0.33^{*}$ & $0.88^{* *}$ \\
\hline
\end{tabular}

*significative $(\mathrm{P}<0.05)$; **significative $(\mathrm{P}<0.01)$.

DMIa (\%LW) - dry matter intake in percentage of live weight; DMIb (g/kgMW) dry matter intake in gram per kilogram of metabolic weight; DCF - daily cost with feeding; FE - feed efficiency; FC - feed conversion.

Table 5 - Adjusted means and standard error of the mean (SEM) for the characteristics intake and performance, according to the residual feed intake (RFI) of feedlot Zebu animals

\begin{tabular}{lccccc}
\hline Item & $\begin{array}{c}\text { Low } \\
\text { RFI }\end{array}$ & $\begin{array}{c}\text { Medium } \\
\text { RFI }\end{array}$ & $\begin{array}{c}\text { High } \\
\text { RFI }\end{array}$ & SEM & P \\
\hline N $^{\circ}$ of animals & 12 & 15 & 13 & - & - \\
Initial LW (kg) & 404 & 406 & 408 & 7.15 & 0.92 \\
Final LW (kg) & 471 & 471 & 473 & 8.58 & 0.97 \\
ADG (kg/day) & 1.11 & 1.11 & 1.18 & 0.07 & 0.70 \\
DMI (kg/day) & $9.51 \mathrm{a}$ & $9.77 \mathrm{~b}$ & $10.00 \mathrm{~b}$ & 0.10 & $<0.01$ \\
DMIa (\%LW) & $2.16 \mathrm{a}$ & $2.24 \mathrm{~b}$ & $2.28 \mathrm{~b}$ & 0.02 & $<0.01$ \\
DMIb (g/kg MW) & $98.9 \mathrm{a}$ & $102.4 \mathrm{~b}$ & $104.3 \mathrm{~b}$ & 0.77 & $<0.01$ \\
FE & 0.11 & 0.12 & 0.12 & 0.007 & 0.46 \\
FC & 8.86 & 8.84 & 9.60 & 0.62 & 0.53 \\
RFI (kg/day) & $-0.213 \mathrm{a}$ & $0.008 \mathrm{~b}$ & $0.222 \mathrm{c}$ & 0.018 & $<0.01$ \\
$\mathrm{RGR}$ & 0.088 & 0.091 & 0.098 & 0.005 & 0.35 \\
KR & 0.011 & 0.011 & 0.011 & 0.001 & 0.87 \\
DCF (R\$/day) & $3.35 \mathrm{a}$ & $3.47 \mathrm{~b}$ & $3.55 \mathrm{~b}$ & 0.04 & 0.01 \\
CG (R\$/kg gain) & 3.07 & 3.14 & 3.41 & 0.22 & 0.53 \\
\hline
\end{tabular}

LW - average live weight; ADG - average daily gain; DMI - dry matter intake; DMIa (\%LW) - dry matter intake in percentage of live weight; DMIb (g/kgMW) dry matter intake in gram per kilogram of metabolic weight; DCF - daily cost with feeding; FE - feed efficiency; FC - feed conversion; RFI - residual feed intake; CG - cost with gain; RGR - relative growth rate; KR - Kleiber ratio. 
of production efficiency, in the Zebu groups studied at this development stage, does not impair the performance (ADG) of the animals. With such evidence, animals with low RFI can be more efficient in the production system, given that they present lower dry matter intake for an equal weight gain. This fact is also observed in the literature (Arthur et al., 2008).

There was no difference between the RFI groups for relative growth rate and the Kleiber ratio, which demonstrates that the RFI groups kept the weight and performance potential similar during the period evaluated. The similarity between the RFI groups for relative growth rate and the Kleiber ratio may be related to the values of the variables (time of assessment, weight and weight gain) utilized for the calculation of these rates, since these values were similar between the RFI groups. Sobrinho et al. (2011), working with Nellore animals, also did not observe difference in relative growth rate or the Kleiber ratio between the different RFI groups.

The RFI in kilogram per day and in percentage of live weight were different between the RFI classes (Table 5), with animals of low RFI presenting the lowest values, which shows that the benefits of the animals with low RFI can also be observed when analyzing the DMI in kilogram per day and in percentage of live weight.

Animals of low RFI presented lower DMIb (Table 5), which suggests that these animals present lower maintenance requirement. This evidence can be related to the positive correlation between average metabolic weight and DMI (Table 3).

The ratio between RFI and maintenance requirement found in this study is similar to those observed in the literature (Liu et al., 1998; Arthur et al., 2006). Lower dry matter intake per unit of metabolic weight in animals of low RFI was also related to a lower protein turnover (Moore et al., 2009) and to the smaller number of times going to the trough and longer idle time (Kelly et al., 2010).

No differences were observed between the RFI groups for characteristics FE and FC (Table 5). This fact is explained by the inexistence of correlation between RFI and FE and by the low correlation value between RFI and FE, as shown previously (Table 3). With this result, one can observe greater accuracy with the use of RFI to evaluate the production efficiency of the animals. This is because, to calculate FC and FE, only ADG and DMI are taken into account, while for the calculation of RFI, in addition to these variables, the metabolic weight of the animals is also considered.

The variation observed in DMI (kg/day) between the animals of low and high RFI promoted reduction of $5 \%$ in daily cost with feeding and per kg of weight gain, for animals of low RFI (Table 5). Regarding expenses with feeding for the animals of both groups to gain $30 \mathrm{~kg}$ live weight, animals of low RFI present reduction of R $\$ 6.00$ in this cost. This reduction in the expenses with feeding for an equal performance indicates the economic benefits of utilizing RFI as a selection criterion in beef cattle breeding programs.

No difference was observed for weight and hot carcass yield between the RFI groups (Table 6).

Besides there being no difference in carcass weight between the RFI groups, all presented hot carcass weight superior to the minimum required by the slaughterhouse freezers, which is $230 \mathrm{~kg}$, as reported by Freitas et al. (2008) and Ítavo et al. (2008).

No differences between the RFI groups were observed for the variables rib-eye area, backfat thickness and rump fat thickness (Table 6). The similarity of the RFI groups for variables backfat and rump fat thickness were expected, since these characteristics did not present correlation as the RFI values (Table 3). Even without any differences between the groups for backfat thickness, the animals of low and high RFI presented backfat thickness values above the minimum standard of $3 \mathrm{~mm}$ required by slaughterhouse freezers (Table 6).

With these results, it is believed that the use of RFI as a selection criterion for the feed efficiency of Zebu animals will not bring damage to the carcass characteristics. In studies reported in the literature, no differences were found between animals of low and high RFI for rib-eye area or backfat thickness in Zebu cattle (Leme et al., 2007; Gomes, 2009). However, in taurine, greater rib-eye area and lower backfat thickness were reported for the most efficient animals (Richardson et al., 2001; Basarab et al., 2003;

Table 6 - Adjusted means and standard error of the mean (SEM) for characteristics performance and carcass quality, according to the residual feed intake (RFI) of feedlot Zebu animals

\begin{tabular}{lccccc}
\hline Item & $\begin{array}{c}\text { Low } \\
\text { RFI }\end{array}$ & $\begin{array}{c}\text { Medium } \\
\text { RFI }\end{array}$ & $\begin{array}{c}\text { High } \\
\text { RFI }\end{array}$ & SEM & P \\
\hline N $^{\circ}$ of animals & 12 & 15 & 13 & - & - \\
HCW, kg & 267 & 269 & 271 & 5.30 & 0.87 \\
HCY, \% & 55.2 & 55.5 & 55.6 & 0.48 & 0.86 \\
EB, kg & 195.6 & 196.9 & 199.3 & 4.37 & 0.81 \\
Bone, kg & 43.1 & 44.5 & 45.1 & 1.03 & 0.39 \\
BFT, mm & 4.1 & 4.2 & 4.4 & 0.31 & 0.73 \\
RFT, mm & 5.7 & 6.0 & 6.3 & 0.47 & 0.67 \\
REA, cm ${ }^{2}$ & 59.1 & 60.9 & 63.0 & 1.74 & 0.37 \\
Liver, kg & 4.35 & 4.32 & 4.47 & 0.12 & 0.35 \\
Kidneys, kg & 0.86 & 0.88 & 0.90 & 0.03 & 0.65 \\
Heart, kg & 1.53 & 1.56 & 1.57 & 0.05 & 0.88 \\
Lungs, kg & 3.38 & 3.42 & 3.45 & 0.11 & 0.91 \\
\hline
\end{tabular}

REA - rib-eye area; BFT - backfat thickness; RFT - rump fat thickness; HCW - hot carcass weight; HCY - hot carcass yield; EB - equivalent boning. 
Herd et al., 2003). According to the results of this study and those found in the literature, it is believe that, possibly, there is synergism between genotype (taurine and Zebu) and RFI for the characteristics rib-eye area, backfat thickness and rump fat thickness.

There was no difference for the weight of any of the viscera between RFI groups (Table 6), which indicates that, possibly, the difference in the maintenance requirement between the animals is linked to the metabolism of the muscle tissue and other tissues, rather than to the metabolism of the viscera evaluated, as presented by Basarab et al. (2003).

There was no alteration in the meat quality parameters with RFI adopted as selection criterion for feed efficiency (Table 7).

Similar results were reported in the literature: Barker et al. (2006), working with taurine of the Angus breed did not observe difference in the meat quality parameters between animals of low and high RFI. Working with Nellore cattle, Gomes (2009) also did not find difference in the meat quality parameters between animals in the different RFI groups.

Table 7 - Adjusted means and standard error of the mean (SEM) for the meat quality characteristics, according to the residual feed intake (RFI) of feedlot Zebu animals

\begin{tabular}{lccccc}
\hline Item & $\begin{array}{c}\text { Low } \\
\text { RFI }\end{array}$ & $\begin{array}{c}\text { Medium } \\
\text { RFI }\end{array}$ & $\begin{array}{c}\text { High } \\
\text { RFI }\end{array}$ & SEM & P \\
\hline $\mathrm{N}^{\circ}$ of animals & 12 & 15 & 13 & - & - \\
pH24 & 5.61 & 5.62 & 5.67 & 0.06 & 0.75 \\
SF (kgf) & 4.10 & 4.37 & 4.57 & 0.27 & 0.45 \\
LWC (\%) & 24.9 & 25.5 & 25.6 & 0.82 & 0.27 \\
WHC (\%) & 72.7 & 73.2 & 75.6 & 1.20 & 0.20 \\
$\mathrm{~L}^{*}$ & 38.26 & 38.57 & 38.71 & 0.89 & 0.93 \\
$\mathrm{a}^{*}$ & 14.90 & 15.07 & 15.13 & 0.25 & 0.79 \\
$\mathrm{~b}^{*}$ & 12.97 & 13.56 & 13.77 & 0.39 & 0.34 \\
\hline
\end{tabular}

pH24 - pH 24 hours after slaughter; SF (kgf) - shear force, expressed in kilogram force (kgf); LWC - loss of weight by cooking; WHC - water holding capacity;

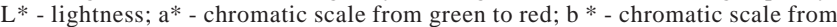
blue to yellow.

\section{Conclusions}

The confinement of Zebu animals which present low residual feed intake (the most efficient) enables better production efficiency with reduction in the costs with feeding, without promoting alterations in performance, carcass characteristics or meat quality.

\section{References}

ABULARACH, M.L.S.; ROCHA, C.E.; FELÍCIO, P.E. Características de qualidade do contrafilé (músculo longissimus dorsi) de touros jovens da raça Nelore. Ciência e Tecnologia de Alimentos, v.18, n.2, p.205-210, 1998.
ARTHUR, J.P.F.; HERD, R.M. Residual feed intake in beef cattle. Revista Brasileira de Zootecnia, v.37, p.269-279, 2008 (supl. especial).

ARTHUR, P.F.; HERD, R.M. Selection for growth and feed efficiency - the australian experience. Journal Integrated Field Science, v.3, n.1, p.59-66, 2006.

ARTHUR, P.F.; ARCHER, J.A.; HERD, R.M. Feed intake and efficiency in beef cattle: overview of recent Australian research and challenges for the future. Australian Journal Experimental Agriculture, v.44, n.7-8, p.361-369, 2003.

BASARAB, J.A.; PRICE, M.A.; AALHUS, J.L. et al. Residual feed intake and body composition in young cattle. Canadian Journal of Animal Science, v.83, n.2, p.189-204, 2003.

BRASIL. Ministério da Agricultura e do Abastecimento. Regulamento da inspeção industrial e sanitária de produtos de origem animal. Brasília: MMA, 1997. 241p.

CABRAL, L.S.; SANTOS, J.W.; ZERVOUDAKIS, J.T. et al. Consumo e eficiência alimentar em cordeiros confinados. Revista Brasileira de Saúde e Produção Animal, v.9, n.4, p.703-714, 2008.

CASALI, A.O.; DETMANN, E.; VALADARES FILHO, S.C. et al. Influência do tempo de incubação e do tamanho de partículas sobre os teores de compostos indigestíveis em alimentos e fezes bovinas obtidos por procedimentos in situ. Revista Brasileira de Zootecnia, v.37, n.2, p.335-342, 2008.

COOPERATIVE RESEARCH CENTRE FOR CATTLE AND BEEF QUALITY. CRC for beef genetic technologies prospectus. Armidale, 2004. 16p.

FERNANDES, A.R.M.; SAMPAIO, A.A.M.; HENRIQUE, W. et al. Características da carcaça e da carne de bovinos sob diferentes dietas, em confinamento Arquivo Brasileiro de Medicina Veterinária e Zootecnia, v.60, n.1, p.139-147, 2008.

FREITAS, A.K.; RESTLE, J.; PACHECO, P.S. et al. Características de carcaças de bovinos Nelore inteiros vs castrados em duas idades, terminados em confinamento. Revista Brasileira de Zootecnia, v.37, n.6, p.1055-1062, 2008.

GOMES, R.C. Metabolismo proteico, composição corporal, caracteristica de carcaça e qualidade de carne de novilhos Nelore (Bos indicus) em função do consumo alimentar residual. 2009. 93f. Tese (Doutorado em Qualidade e Produtividade Animal) - Faculdade de Zootecnia e Engenharia de Alimentos, Pirassununga.

GREINER, S.P.; ROUSE, G.H.; WILSON, D.E. et al. Accuracy of prediction weight and percentage of beef carcass retail product using ultrasound and live animal measures. Journal of Animal Science, v.81, n.2, p.466-473, 2003.

HERD, R.M.; ARCHER, J.A.; ARTHUR, P.F. Reducing the cost of beef production through genetic improvement in residual feed intake: opportunity and challenges to application. Journal of Animal Science, v.81, n.1, p.9-17, 2003 (suppl.).

ÍTAVO, L.C.V.; DIAS, A.M.; ÍTAVO, C.C.B.F. et al. Desempenho produtivo, características de carcaça e avaliação econômica de bovinos cruzados, castrados e não-castrados, terminados em pastagens de Brachiaria decumbens. Arquivo Brasileiro de Medicina Veterinária e Zootecnia, v.60, n.5, p.1157-1165, 2008.

KELLY, A.K.; McGEE, M.; CREWS, D.H. et al. Effect of divergence in residual feed intake on feeding behavior, blood metabolic variables, and body composition traits in growing beef heifers. Journal of Animal Science, v.88, n.1, p.109-123, 2010.

LADEIRA, M.M.; VALADARES FILHO, S.C.; COELHO DA SILVA, J.F. et al. Consumo e digestibilidades aparentes totais e parciais de dietas contendo diferentes níveis de concentrados em novilhos nelore. Revista Brasileira de Zootecnia, v.28, n.2, p.395-403, 1999.

LANNA, D.P.; ALMEIDA, R. Residual feed intake, um novo critério para seleção? In: SIMPÓSIO DA SOCIEDADE 
BRASILEIRA DE MELHORAMENTO ANIMAL, 5., 2004, Pirassununga. Anais... Pirassununga: SBMA, 2004. 12p. Available at: <http://www.sbmaonline.org.br/anais/v/palestras/ palest04.pdf>. Accessed on: Dec. 10, 2010.

LEME, P.R.; GOMES, R.C. Características de carcaça de novilhos nelore com diferentes consumo alimentar residual. In: REUNIÓN ASOCIACÓN LATINOAMERICANA DE PRODUCCIÓN ANIMAL, 20., 2007, Cuzco. Anais... Cuzco: ALPA, 2007. v.15. p.453. (CD-ROM).

LIU, M.F.; GOONEWARDENE, L.A.; MAKARECHIAN, M. et al. A study on feed efficiency of young beef bulls in a test station. In: WORLD CONGRESS ON GENETICS APPLIED TO LIVESTOCK PRODUCTION, 6., 1998. Proceending... Armidale: [s.n.], 1998. v.23, p.217-220.

LOPES, L.S.; LADEIRA, M.M.; MACHADO NETO, O.R. et al. Viabilidade econômica da terminação de novilhos Nelore e Red Norte em confinamento na região de Lavras, MG. Ciência e Agrotecnologia, v.35, p.774-780, 2011.

MCDONAGH, M.B.; HERD, R.M.; RICHARDSON, E.C. et al. Meat quality and the calpain system of feedlot steers following a single generation of divergent selection for residual feed intake. Australian Journal of Experimental Agriculture, v.41, n.7, p.1013-1021, 2001.

MENEZES, L.F.G.; BRONDANI, I.L.; ALVES FILHO, D.C. et al. Características da carcaça de novilhos de diferentes grupos genéticos, terminados em confinamento, recebendo diferentes níveis de concentrado. Ciência Rural, v.35, n.5, p.1141-1147, 2005.
MOORE, S.S.; MUJIBI, F.D.; SHERMAN, E.L. Molecular basis for residual feed intake in beef cattle. Journal of Animal Science, v.87, n.4, p.41-47, 2009 (suppl.)

NKRUMAH, J.D.; BASARAB, J.A.; PRICE, M.A. et al. Different measures of energetic efficiency and their phenotypic relationships with growth, feed intake, and ultrasound and carcass merit in hybrid cattle. Journal of Animal Science, v.82, n.8, p.2451-2459, 2004.

ROÇA, R.O. Modificações post-mortem. Botucatu: Laboratório de Tecnologia dos Produtos de Origem Animal. Available at: $<$ http://www.fca.unesp.br>. Accessed on: Sept. 12, 2009.

SALIBA, E.O. Uso de indicadores: passado, presente e futuro. In: TELECONFERÊNCIA SOBRE O USO DE INDICADORES EM NUTRIÇÃO ANIMAL, 1., 2005, Belo Horizonte. Anais... Belo Horizonte: UFMG, 2005.

SILVA, D.J.; QUEIROZ, A.C. Análise de alimentos: métodos químicos e biológicos. Viçosa, MG: UFV, 2002. 235p.

SOBRINHO, T.L.; BRANCO, R.H.; BONILHA, S.F.M. et al. Residual feed intake and relationships with performance of Nellore cattle selected for post weaning weight. Revista Brasileira de Zootecnia, v.40, n.4, p.929-937, 2011.

VALADARES FILHO, S.C.; MORAES, E.H.B.K.; DETMANN, E. Perspectivas do uso de indicadores para estimar o consumo individual de bovinos alimentados em grupo. In: REUNIÃO ANUAL DA SOCIEDADE BRASILEIRA DE ZOOTECNIA, 43., 2006, João Pessoa. Anais... João Pessoa: SBZ, 2006.

WANG, Z.; NKRUMAH, J.D.; LI, C. et al. Test duration for growth, feed intake, and feed efficiency in beef cattle using the GrowSafe System. Journal of Animal Science, v.84, n.9, p.2289-2298, 2006. 